БОЛ У ЛАКТУ - ЗНАЧАЈ ЗА ПРИМАРНУ ЗДРАВСТВЕНУ ЗАШТИТУ

Астрит Бериша ${ }^{1}$, Милан Живковић ${ }^{2}$

\title{
PAIN IN THE ELBOW - THE IMPORTANCE FOR THE PRIMARY HEALTH CARE
}

Astrit Berisha, Milan Živković

\section{Сажетак}

Бол у лакту је чест разлог за јављање лекару, и може бити велика препрека у обављағу свакодневних активности и обавеза. Може да се јави у сваком узрасту, а најчешће се јавља код физички активних особа. Разлози за појаву бола у лакту су различите природе. Најчешће су то спољашне трауме, дислокације, реуматске инфламаторне и дегеренативне болести итд. Код људи који се баве спортом може се јавити повреда у лакту позната под називом тениски лакат или стручно латерални епикондилитис, и голферски лакат или медијални епикондилитис.

За лекара у примарној здравственој заштити важно је да благовремено постави дијагнозу и да оне случајеве који су праћени, осим болом, отоком, ирвенилом и ослабљеним покретима (ургентни случајеви) шаље даље у установе секундарне зравствене заштите, јер они захтевају специјалистичко лечење.

Кључне речи: Бол, лакат, лечење, оток, црвенило.

\section{Summary}

Elbow pain is a common reason why people appear doctor, and it can be a major obstacle in performing daily activities and responsibilities. It can occur at any age, but most often in physically active people. The reasons for the emergence of pain in the elbow are of different nature. Most often these are externals trauma, dislocations, rheumatic inflammatory and degenerative diseases, etc. People who participate in sports injuries can occur in the elbow, which is known as tennis elbow or lateral epicondylitis, and golf elbow, or medial epicondylitis.

For doctors in primary health care it is important to make a diagnosis timely. and that those cases which were followed except pain, with swelling, redness, impaired movement (emergency cases) passed on to institutions of secondary health care, because they require specialist treatment.

Key words: pain, elbow, treatment, swelling, redness.

\footnotetext{
${ }^{1}$ Астрит Бериша, Дом здравља Прешево.

${ }^{2}$ Милан Живковић, Дом здравља Врањска Бања.
} 


\section{УВОД}

Б ол у лакту је веома чест симптом са којим пацијенти долазе у примарну здравствену заштиту, а разлог бола може бити смештен у било ком делу лакта, укључујући тетиве, бурсе, кости и нерве. Најчешће се јавља на спољашњој страни доњег дела надлактице. Неке болести изазивају само болове без других уочљивих знакова, док велики број болести прате про- мене као што су оток, промене боје коже, деформације и губитак функције зглоба. Може да се појави у било ком узрасту.

Овај симптом је изазов за лекара у примарној здравственој заштити и неопходно је потпуно разјашњавање појаве како би се приступило сврсисходном и циљаном лечењу. У томе могу доста помоћи алгоритми и степенасти приступ проблему (Слика 1).

Слика 1. Алгоритам терапије бола у лакту

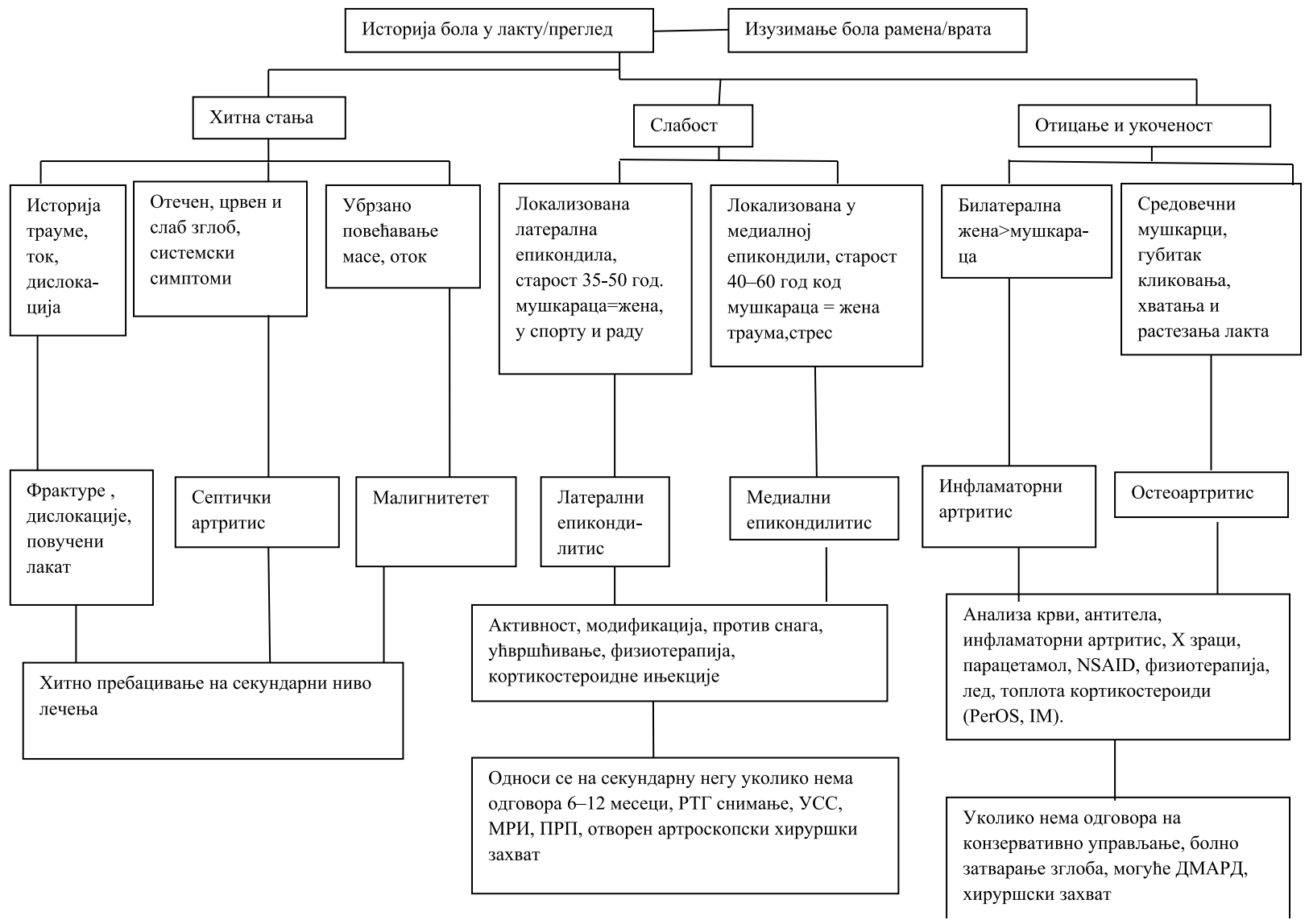

ДМАРД - модификовање антиреуматиских лекова, ПРП - смеса богата плателатом, РОМ опсег покрета, МРИ - магнетна резонанца, УСС - ултразвучно скенирање.

Према приложеном алгоритму и на основу емпиријских доказа неопходно је најпре искључити ургентна стања као што су отоци и дислокације настали после траума, слабост, отечен зглоб који се брзо повећава, а која могу довести до бола у лакту. Она захтевају ургентно упућивање на секундарни ниво лечења.

\section{ПРОЦЕНА БОЛА}

Процена бола приликом прегледа пацијента је кључ дијагнозе, нарочито систематски приступ процени природе, почетка и трајања бола, уз праћење придодатих симптома. Треба, такође, испитати активности и механизме настанка повреде. 
Трауматски почетак бола у доминантној руци који погађа спољашњи део лакта са повременим зрачењем у подлактици карактеристичан је за тениски лакат, тј. ерісоndylitis lateralis. Може се јавити после трауме, нпр. приликом ношења врло тешког терета, али је чешћи код професија које захтевају учестале и поновљене покрете руке везане за одређена занимања или спортске дисциплине. Јавља се код 20-50\% тенисера, мада је једнако уобичајен и код занатлија као што су водоинсталатери, фарбари, столари, баштовани, затим код особа које раде много за компјутером, виолиниста и других.

Бол који се постепено развија у унутрашњем делу лакта доминантне руке током дужег времена карактеристичан је за тзв. лакат играча голфа, тј. epicondylitis medialis. Јавља се најчешће између четрдесете и шездесете године живота. У почетку сејавља локализован бол у пределу лакта, обично у јутарњим часовима, а појављује се и у току активности као што је рад са шрафцигером. Касније, пацијенти осећају бол и приликом обављања свакодневних активности попут подизања чаше или шоље, током управљања возилом, руковања и слично. Разлог бола може бити и акутне природе услед ударца у пределу унутрашњег дела лакта, те свакако треба испитати да ли су у историји болести присутни понављани стресови и траума.

Хронични прогресивни бол у лакту са слабијом покретљивошћу лакта и подлактице због укочености указује на остеоартритис.

Удружени болови лакта са укоченошћу и отоком, губитак покретљивости, али и симптоми на другим зглобовима, као и систематски симптоми упућују на инфламаторни артритис, код кога 20-25\% пацијената имају проблеме баш са лактом.

\section{Додатни симптоми}

Укоченост подлактице наводи на артритис или трауму. Укоченост која ограничава савијање у зглобу лакта много више онеспособљава него што ограничава продужавања.
Неуролошки симптоми, као што су укоченост и пецкање, морају бити додатно сагледани. Радикулопатија n. ulnaris се често јавља код медијалног епикондилитиса, остеоартритиса (50\% пацијената) и инфламаторног артритиса.

Бол у врату или рамену може да узрокује бол у лакту. Процена цервикалног дела кичме је изузетно важна ради отклањања сумњи на реуматоидни артритис.

\section{ПРЕГЛЕД ЛАКТА}

Пре прегледа лакта треба прегледати врат и раме да би се искључила радикулопатија и слабост рамена или бол који потиче од њих. Треба урадити Спурлинг тест (притиском на вертекс са савијањем главе на болну страну провоцирају се тегобе) како би се искључила цервикална радикуларна компресија.

Преглед лакта треба извести систематски држећи се уобичајеног приступа: гледај, осети, покрени.

Пацијент мора бити адекватно растерећен од одеће да би се могао урадити комплетан преглед од врата до обе шаке, зато што се увек упоређују обе стране. Испитује се да ли постоји црвенило, оток, атрофија, асиметрија или целокупан деформитет. Посебно треба обратити пажњу на држање тела пацијента како би се проценили знаци у хроничном болу.

Код испитивања зглобова, треба проценити слабу тачку, присуство сумњиве масе и бележити промене у температури. Слабост може настати због тендинитиса бицепса. Слабост палпитације баш испод медијалног епикондила означава медијални епикондилитис. Слабост улнарног нерва (Тинелов знак) може настати као последица задњег или медијалног еpicondylitisa, указујући на улнарну неуропатију. Тешка слабост предњег и латералног epicondyla указује на дијагнозу - латерални епикондилитис. Слабост локализована у облику дисталне до радијалне главе указује на задњу 
интеросерозну нервну компресију, диференцијалну дијагнозу бола бочног лакта (коегзистентног у латералном епикондилитису у 5\% случајева). Позадина, патологија у трицепсном мишићу, процесу олекранона и његовој бурси може да доведе до слабости. Такође, треба проверити да ли постоји крепитација у лакту ради искључења фрактуре главе радијуса, артритис или слабост тела.

Испитати активни или пасивни РОМ, прво узимајући у обзир активне покрете. Хиперекстензија је уобичајена код жена и нормална уколико је билатерална, а у одсутности траума. Ограничење пуне екстензије је дијагностична за остеоартритис. Флексија, супинација и пронација треба, такође, да буду тестиране. Покрет ручног зглоба може, такође, бити процењен због подељене мускулатуре између ручног зглоба и лакта.

Завршити процену изводећи неуроваскуларни преглед. Укључити процену других зглобова и потпунити преглед уколико је потребно.

\section{Остала испитивања}

Анализе крви (крвна слика, број еритроцита, седиментација, реуматоидни фактор и аутоантитела) треба урадити уколико се сумња на инфламаторни артритис. Нативна радиографија је нормална у тендинопатији и није индикована. Стандардна антеропостериорна и лателарна радиографија може бити урађена уколико је бол удружен са укоченошћу који наводи на артритис или трауму.

Ултазвучни преглед треба да уради искусни професионалац и он има различиту сензитивност и специфичност. Магнетна резонанца се најбоље користи за дијагнозу повреда лигамената. Ултразвук и магнетна резонанца су корисне у секундарном лечењу.

Електромиографија је корисна уколико се сумња на дисфункцију нерва.

\section{ЛЕЧЕЊЕ БОЛА УЛАКТУ}

Лечење треба да буде усмерено на ублажавање бола, враћање нормалног физичког функционисања и одржавање пацијентове способности да ради.

Терапеутски модалитети, као што су одмор, аналгезија и стероидне инјекције, изазивају привремено ослобађање бола, али морају бити коришћени само као део ширег плана у лечењу.

Организовање примарног лечења тендинопатије има за циљ смањење стреса и појачање снаге оштећених тетива. Одмор мора бити релативан и пацијент мора да избегава активности које погоршавају стање. Учвшћивање (завој око тела мишића) умањује стрес, док вежбе рехабилитације и физиотерапија побољшавају снагу мишића. Физиотерапија је показала 91\% ефективности у 52 недеље. Инјекције кортикостероида могу да обезбеде краткотрајно олакшање симптома, али могу бити повезане са горим резултатима. Коришћење botulinum toxin смеса обогаћених плателетом за лечење тендинопатије у последње време се појачало, али не постоји клинични доказ њихове суперионости у односу на плацебо. Упућивање у установу секундарне здравствене заштите је указано после перзистентних симптома упркос 6-12 месеци конзервативног третмана. Па ипак, резултати после хируршког захвата указују на то да 25\% пацијената још годину дана има болове.

Артритис може бити третиран неоперативним путем разним модификацијама, NSAID агенсима у инфламаторним артритисима, стероидима (орално или интрамускуларно), стављањем удлаге или коришћењем леда и топлоте. Индикације за упућивање на секундарну негу су последица неуспеха лечењем неоперативним путем, сметње при свакодневном животу и бол у лакту. 
Примарна нега болног лакта може изискивати много месеци конзервативног управљања, истрајност са вежбама за рехабилитацију и физиотерапију. Проблеми који настају резултирају доготрајнији боловима без хируршког захвата. У том случају се саветује пацијенту да оде на краткотрајно боловање да би се опоравио. Лечење треба да буде прилагођено сваком пацијенту и преглед после 2 до 4 недеље зависи од јачине бола, и то је разумна могућност.

\section{ЗАКЉУЧАК}

Бол у лакту је чест разлог за јављање лекару. За лекара у примарној здравственој заштити важно је да благовремено постави дијагнозу бола у лакту и да ургентне случајеве упути у установе секундарне зравствене заштите уколико захтевају специјалистичко лечење. Овај симптом је изазов за лекара у примарној здравственој заштити и како би се проблем проблем бола у лакту потпуно решио, неопходно је приступити сврсисходном и циљаном лечењу, користи се алгоритмом и степенастим приступом проблему. Процена бола приликом прегледа пацијента је кључ за постављање дијагнозе. Пре прегледа лакта треба прегледати врат и раме. Лечење треба да буде усмерено на ублажавање бола, враћање нормалног физичког функционисања и одржавање пацијентове способности да ради.

\section{ЛИТЕРАТУРА}

1. Trumble T, Cornawall R, Budoff J. Core knowledge in orthopedics: hand, elbow and shoulder. Philadelphia, PA: Mosby Elsevier, 2005.

2. Boyer M, ed. American Academy of Orthopaedics Surgeons (AAOS) comprehensive orthopaedic: a review, 2nd edn. Rosemont, IL: AAOS, 2014.

3. Ahmad ZA, Siddiqui N, Malik SS, et al. Lateral epicondylitis: a review of pathalogy and menagment. Bone Joint J 2013.

4. Murtaugh B, Ihm JM. Eccentric training for the treatment of tendinopathies. Curr Sports Med Rep 2013.
5. Coombes BK, Bisset L, Vicenzino

B. Efficacy and safety of corticosteroid injections and toher injections for menagment of tendinopathy: a systematic review of randomized controlled trials. Lancet 2010.

6. Papatheodorou LK,Baratz ME, Sotereanos DG. Elbow arthritis: current concepts. J Hand Surg Am 2013.

7. Arthritis Research UK, Chartered Society of Physiotherapy. Exercise advice: tennis elnow. http://www.csp.org.uk/your-health/ exercise-advice/tennis-elbow (accesed, 21 Sep 2015).

Контакт: Астрит Бериша, Дом здравља Прешево, e-mail: dr.astrit78@gmail.com. 